\title{
Accepting EU Private International Law Standards into the Legal System of Bosnia and Herzegovina: What Can be Done While Waiting for Godot?
}

\author{
JASMINA ALIHODŽIĆ, ZLATAN MEŠKIĆ \& ANITA DURAKOVIĆ
}

\begin{abstract}
The process of accession of Bosnia and Herzegovina to the EU implies the introduction of EU standards on Private International Law into its internal legislation. This paper includes considerations related to the ways of implementation of the reform of private international law, having in mind the complex constitutional structure of Bosnia and Herzegovina, especially the division of competencies between the State and its entities. Bearing in mind the complexity of the decision-making process of different levels and the inability to reach political consensus on the reform, the article emphasises alternative mechanisms for introducing EU standards in the field of private international law into the legal system in Bosnia and Herzegovina. Given the external competence of the EU in its relations with third countries, this article gives a thorough analysis of the possibility of concluding international agreements in the field of private international law.
\end{abstract}

Keywords: - private international law reform in Bosnia and Herzegovina - Stabilization and Association Agreement - EU external competence $\bullet$ Lugano Convention • Sarajevo Convention •

Correspondence Address: Jasmina Alihodžić, PhD, Associate Professor, University of Tuzla, Faculty of Law, Tuzla, Bosnia \& Herzegovina, e-mail: jasmina.altumbabic@untz.ba. Zlatan Meškić, PhD, Associate Professor, Prince Sultan University, College of Law, Riyadh, Saudi Arabia, e-mail: zmeskic@psu.edu.sa. Anita Duraković, PhD, Associate Professor, University "Džemal Bijedić”, Faculty of Law, Mostar, Bosnia \& Herzegovina, e-mail: anita.durakovic@unmo.ba. 
Bosnia and Herzegovina (hereinafter referred to as: $\mathrm{B} \& \mathrm{H}$ ) is a country in the process of joining the EU. This necessarily implies harmonisation of its internal legal order with the acquis communautaire, inter alia, in the field of private international law. This article includes considerations relating to the standards of private international law in the EU and the modes of their introduction into the legal system of $\mathrm{B} \& \mathrm{H}$. The paper is divided into three parts.

In the first part of the paper, the authors give a short overview of the existing Private International Law Act in $\mathrm{B} \& \mathrm{H}$, with specific emphasis on the problem of the constitutional division of competencies for its regulation, as well as other areas of private law. The second part is related to the consideration of the modes for the implementation of the reform of private international law, bearing in mind the existing constitutional capacities and obligations of $\mathrm{B} \& \mathrm{H}$ derived from the Stabilization and Association Agreement ${ }^{1}$ (hereinafter: SAA). By this Agreement, $\mathrm{B} \& \mathrm{H}$ has committed to harmonise its legislation with the acquis communautaire. This harmonisation necessarily entails the implementation of the reform process in all areas defined by the Agreement, bearing in mind primarily the areas that are essential for the proper functioning of the internal market in $\mathrm{B} \& \mathrm{H}$, including the area of private international law. Alternative possibilities for the implementation of the EU private international law standards into $\mathrm{B} \& \mathrm{H}$ legislation are given in the third part of the paper. The authors especially emphasise the importance of the Hague Conventions acceeded to by the EU, as well as the EU Regulations providing the possibility of EU Member States to negotiate and conclude the agreements with third states, including B\&H, despite the external competence of the EU in this field.

\section{Private international law legislation in $\mathbf{B} \& \mathbf{H}$}

The dissolution of former Yugoslavia and its legal system has left a significant mark not only on the public subjectivity of the successor states but also on their legislation in the field of private law relations. Unlike other successor states which have already adopted new private international law acts or where such an act is still in the decision-

\footnotetext{
${ }^{1}$ The agreement was signed on 16. 6. 2008 in Luxembourg. It entered into force in 2015.
} 


\section{LEXONOMICA \\ J. Alihodžić, Z. Meškić \& A. Duraković: Accepting EU Private International Law Standards into the Legal System of Bosnia and Herzegovina: What Can Be Done While

making stage,${ }^{2} \mathrm{~B} \& \mathrm{H}$ is still applying The Yugoslav Act on Resolving Conflicts of Laws with Legal Provisions of other Countries in Certain Relations (hereinafter: PIL Act $\mathrm{B} \& \mathrm{H}^{3}$ ), by virtue of Anex II to the Constitution of $\mathrm{B} \& \mathrm{H}$ which provided the continuity of all the legal provisions which are not in conflict with the current Constitution. ${ }^{4}$

The Yugoslav PIL Act B\&H has been incorporated into the legislation of one of the entities of $\mathrm{B} \& \mathrm{H}$, named the Federation of $\mathrm{B} \& \mathrm{H}$, by virtue of the Regulation with Legal Force on Acceptance and Application of the Federal Laws which have been applied as Republic Laws in B\&H. This has also been confirmed by the Act on the Confirmation of the Regulations with Legal Force. ${ }^{5}$ At the same time, Article 12 of the Constitutional Act for the Implementation of the Constitution of the Republic of Srpska, provided for the acceptance of the same Act in the other entity of B\&H named the Republic of Srpska (hereinafter: R. Srpska).

The problem of regulating private law relations with an international element in $\mathrm{B} \& \mathrm{H}$ is a consequence of a division of competences in a state with a complex constitutional organisation. The concept accepted in the Constitution of $\mathrm{B} \& \mathrm{H}$ is the enumeration of competences of the $\mathrm{B} \& \mathrm{H}$ institutions (Article III/1.) with the presumption of competence in favour of the entities (Article III/3.a). B\&H is a complex state, consisting of two entities - the R. Srpska and Federation of B\&H, as well as Brcko District.

Besides, the R. Srpska is organised in accordance with the unitary principle, while the Federation of B\&H consists of 10 cantons, all having the status of federal units in this entity. Therefore, the area of private law relations, including private international law, has been brought under the jurisdiction of R. Srpska and the cantons in the

\footnotetext{
${ }^{2}$ Slovenia, FYR of Macedonia, Croatia and Montenegro have adopted new Private International Law Acts. In Serbia a Draft Act harmonised with EU law is still waiting for adoption.

${ }^{3}$ Official Gazette of the Socialist Federal Republic of Yugoslavia, No. 43/82 and 72/82.

${ }^{4}$ The current Constitution of $\mathrm{B} \& \mathrm{H}$ is a part of the international agreement by which the war was ended there and which also established the current constitutional order. The continuity of legal provisions from the preDayton period, which are not in a collision with the Dayton Peace Agreement has been provided by virtue of Annex II to the Constitution of B\&H.

${ }^{5}$ Official Gazette B\&H, No. 13/94.
} 
Federation of B\&H, provided that the Federation of B\&H has taken over the capacity from the cantonal level of authorities. ${ }^{6}$

Practically, it means that two entities in B\&H (R. Srpska and the Federation of B\&H) and District Brčko apply the same PIL Act B\&H in the administrative territory under their respective jurisdictions. Accordingly, to incorporate the PIL Act B\&H into $\mathrm{B} \& \mathrm{H}$ legislation it is necessary to undertake certain technical and content changes. However, this has not been done zet. Therefore, in connection to the application of this Act, there are terms which reflect the legal order of the former state (Muminović, 1999: 234). For example, when referring to the public policy exeption, Article 4 of the PIL Act B\&H still talks about "fundamentals of the social system established by the Constitution of the Federal Republic of Yugoslavia".

Although at the time it was adopted, the PIL Act B\&H was considered one of the most prominent codifications of private international law, it can be said that this Act is now outdated. For example, it fails to recognise certain private international law concepts which have become deeply ingrained not only in EU instruments, but also in almost all the contemporary national codifications in this field. The missing concepts include overriding mandatory rules, provisions on the name of natural persons, a general escape clause, party autonomy in wider spheres of private international law, protective jurisdiction rules, and habitual residence as a connecting factor, especially in the field of international family law, etc. Therefore, it is evident that the PIL legislation in B\&H requires thorough reform, not only due to the obligation to introduce EU private inernational law standards into national legislation, but also the obligation to harmonise it with the acquis communautaire.

\footnotetext{
${ }^{6}$ In the meanwhile, the Federation of B\&H has taken over a significant part of cantonal legislative competence by adopting laws in almost all fields of civil and criminal law, which according to a literal interpretation of the Constitution of the Federation of B\&H belong to the competence of cantonal legislative authorities. These laws have never been challenged before the Constitutional Court on the grounds of lack of legislative competence of the Federation of $\mathrm{B} \& \mathrm{H}$ and are still in force. Therefore, it might be considered that there has been a de facto change in the Constitution of the Federation of $\mathrm{B} \& \mathrm{H}$ regarding the competence to legislate in certain areas.
} 


\section{Private international law reform in $\mathrm{B} \& \mathrm{H}$ and the $\mathrm{EU}$ integration process}

\subsection{The legal position of international agreements in $\mathrm{B} \& \mathrm{H}-$ the SAA}

Implementation of private international law reform as well as other private law areas is inevitably intermingled and dependant on very complex state organization namely the division of competences between state and entity level on one side, and allocation of competences inside the entity of Federation of B\&H between entity and cantonal level, on the other side.

According to Article III/3b of the $\mathrm{B} \& \mathrm{H}$ Constitution, the general principles of international law are a constituent part of the $\mathrm{B} \& \mathrm{H}$ legal order. Among these principles, the most significant is pacta sunt servanda, implying a consistent fulfillment of international obligations and responsibility of the state in accordance with international law.

However, in the case of $\mathrm{B} \& \mathrm{H}$, non-fulfillment of an international commitment means at the same time a breach of Article III/3b of the B\&H Constitution. This would always be the case if the international commitment was not fulfilled or national legislation did not comply with that commitment. This is followed by the practice of the B\&H Constitutional Court in the case U-5/09. ${ }^{7}$ Examining the constitutionality of the Law on Protection of Domestic Production ${ }^{8}$ in order to determine its compatibility with the CEFTA agreement, ${ }^{9}$ the Court took the view that the nonfulfillment of the international commitment represented at the same time a violation of the B\&H Constitution. The Court said: "Article III/3b of the B\&H Constitution was violated in a situation when a national law was not in compliance with pacta sunt servanda - international law principle, according to which "each agreement in force was obligatory for contracting parties which should obey it in good faith", or when it was not in compliance with the provisions of an international agreement which B\&H was a party thereto."

\footnotetext{
${ }^{7}$ U-5/09, Official Gazette, No. 18/10, 9. 3. 2010.

${ }^{8}$ Official Gazette B\&H, No. 49/09. The B\&H Constitutional Court repealed the Law.

${ }^{9}$ CEFTA (eng: Central European Free Trade Association).
} 
Commitments from the SAA must be observed in the context of the previously mentioned facts. The SAA imposes the obligation for B\&H to harmonise its national legislation, including the field of private international law, with the acquis communautaire. The precondition for fulfillment of these commitments, as well as the implementation of the SAA in general, is the proper functioning of the free and single market in $\mathrm{B} \& \mathrm{H}$. At the same time, providing for the proper functioning of the market in $\mathrm{B} \& \mathrm{H}$ is a constitutional commitment for all levels of authorities in $\mathrm{B} \& \mathrm{H}$ (Article I/4. B\&H Constitution, subpart 4 of the Preamble). Besides, mutual harmonisation of legal acts in the domain of private law relations, adopted on the entity level, is presumed to be part of establishing the single market and market economy in $\mathrm{B} \& \mathrm{H}$. By mutual harmonisation of legal acts in the domain of private law relations, $\mathrm{B} \& \mathrm{H}$ fulfills the commitments related to the $\mathrm{EU}$ integration process harmonising the $\mathrm{B} \& \mathrm{H}$ legal system with the EU acquis.

Pursuant to Article 1(2) of the SAA, aligning B\&H legislation with that of the EU, as well as completing the transition into a functioning market economy, have been defined as top priority goals of the association process. Article 70 of the SAA is completely dedicated to the commitment to implement the reform in order to harmonise that legislation. ${ }^{10}$ Pursuant to Article 70(2) of the SAA, this approximation shall start on the date of signing of this Agreement, and shall gradually extend to all the elements of the Union acquis. Within the meaning of Article 70(3), approximation shall, at an early stage, focus on fundamental elements of the internal market acquis as well as on other trade-related areas. At a further stage B\&H shall focus on the remaining parts of the acquis. The aforementioned commitments imposed the obligation of private international law reform in $\mathrm{B} \& \mathrm{H}$, at least in a later stage of the accession process.

\footnotetext{
${ }^{10}$ The Parties recognise the importance of the approximation of the existing legislation of $\mathrm{B} \& \mathrm{H}$ to that of the Community and of its effective implementation. B\&H shall endeavour to ensure that its existing laws and future legislation will be gradually made compatible with the Community acquis. B\&H shall ensure that existing and future legislation will be properly implemented and enforced.
} 


\section{LEXONOMICA \\ J. Alihodžić, Z. Meškić \& A. Duraković: Accepting EU Private International Law Standards into the Legal System of Bosnia and Herzegovina: What Can Be Done While

\subsection{Constitutional capacities for private international law reform}

Given the fact that the legislative competence for private law relations has been asigned to entities and District Brcko, it is necessary to give a short overview of the constitutional capacities for adoption of the new law and the implementation of the private international law reform.

This would constitute a framework for the acceptance of relevant EU standards into the $\mathrm{B} \& \mathrm{H}$ legislation, which at the same time means the implementation of commitments of B\&H in relation to the SAA. Namely, the model of redistribution of competences between the state and entity level of governance, as stated before, starts with the precise enumeration of the state competences, while the other issues have been asigned to the competence of entities. ${ }^{11}$ It is evident that private international law issues are not in the legislative competence of the state institutions.

However, the Article III/5 of the B\&H Constitution provides for the possibility of redistribution of responsibilities between the state and entity level, and consequently taking over the responsibilities by the state level:

- In such matters as agreed by the Entities;

- in matters provided for in Annexes 5 through 8 to the General Framework Agreement;

- in matters which are necessary to preserve the sovereignty, territorial integrity, political independence, and international personality of $\mathrm{B} \& \mathrm{H}$, in accordance with the division of responsibilities between the institutions of $\mathrm{B} \& \mathrm{H}$.

It is deemed that a valid constitutional basis for the transfer of responsibilities exists if any of the abovementioned conditions have been fulfilled. This means that responsibility in any field can take place without the explicit consent of the entity. This, in turn, follows from the fact that the previous conditions are, technically

\footnotetext{
${ }^{11}$ In accordance with the provisions of Arts III/1 i III/3a, responsibilities of the state Institutions of B\&H include the following questions: foreign policy, foreign trade policy, customs policy, monetray policy as provided in Article VII, finances of the institutions and for the international obligations of $\mathrm{B} \& \mathrm{H}$, immigration, refugee and asylum policy and regulation, international and inter-Entity criminal law enforcement, including relations with Interpol, establishment and operation of common and international communication facilities, regulation of interEntity transportation and air traffic control.
} 
speaking, separated by semicolons (;), which means that each of them, individually, is considered a sufficient constitutional basis for the assumption of responsibility of the state institutions.

This conclusion is confirmed by the practice of the $\mathrm{B} \& \mathrm{H}$ Constitutional Court which, in case No. U-9/00 from 3 November 2001, in proceedings concerning the constitutionality of the Law on State Border Service, took the following attitude: "The allegations of applicants that, under Article III/5.(a) of the Constitution, the Presidency is obliged to ask for prior consent from RS National Assembly to submitt a Proposal on the Law on State Border Service B\&H to the B\&H Parliamentary Assembly are unfounded. Indeed, the aforementioned Article distinguishes three mutually independent hypotheses: B\&Ha shall assume responsibility for (1) such other matters as agreed by the Entities; (2) as provided for in Annexes 5-8 of the General Framework Agreement; or (3) matters that are necessary to preserve the sovereignty, territorial integrity, political independence and international subjectivity of $\mathrm{B} \& \mathrm{H}$, in accordance with the division of responsibilities between the institutions of B\&H under Articles III/3. and III/5. of the Constitution. The Presidency proposed the Law on State Border Service to the Parliamentary Assembly according to the third hypothesis. In this context, Article IV/4.(a) seems to be important, providing that the Parliamentary Assembly enacts legislation that is necessary to implement decisions of the Presidency. Since this article does not require the consent of the entity, the procedure that has been followed by the Presidency prior to the adoption of the Law on State Border Service has not been in conflict with the Constitution of B\&H".

However, given the extremely complex procedure for the adoption of laws at the state level where representatives of entities can hinder the adoption of any law, including those relating to the transfer of responsibilities, this possibility seems to be unlikely. This is especially true if we take into account the current political circumstances and animosity of R. Srpska representatives towards strengthening the state institutions. ${ }^{12}$ The possibility that is more realistic, bearing in mind the aforementioned

\footnotetext{
12 In 2011, The Deutsche Gesellschaft für Internationale Zusammenarbeit (GIZ) or German Development Agency, working in B\&H on behalf of the German Federal Ministry for Economic Cooperation and Development (BMZ) since 1995, together with the B\&H Ministry of Justice had formed the expert group (one of the authors of this paper was supposed to be a member of the group) which was supposed to work on the Draft for the new Private International Law Act in B\&H. However, due to lack of consensus among the representatives of both entities on the level they should bring the PIL Act to, the project did not result in success.
} 


\section{LEXONOMICA \\ J. Alihodžić, Z. Meškić \& A. Duraković: Accepting EU Private International Law Standards into the Legal System of Bosnia and Herzegovina: What Can Be Done While \\ Waiting for Godot?}

circumstances, could be the framework regulation of certain areas at the level of $\mathrm{B} \& \mathrm{H}$, where responsibility to regulate such issues still remains within entities.

In this sense, the Constitution B\&H in Section IV/4 and V/3 establishes that the Parliamentary Assembly of B\&H enacts legislation to implement the decisions of the Presidency of $\mathrm{B} \& \mathrm{H}$, which is the constitutional basis for the adoption of framework legislation, without formally withdrawing the jurisdiction of the entities in areas in which the decision has been made. This means that a binding framework is established at the national level which has to be followed by the entities while adopting their own laws in this area. ${ }^{13}$ In this way, entity legislation can be harmonized in all areas of their jurisdiction. Using this option, the B\&H Framework Law on Higher Education ${ }^{14}$ was enacted, while entities (RS and Federation of B\&H) and the cantons (when it comes to the division of responsibilities within the Federation of $\mathrm{B} \& \mathrm{H})$ regulated this area according to their own laws.

Another possibility for legislative reform in the area of private-law relations with an international element is the coordination between the responsible entity institutions at the institutional level, without making framework legislation and redistribution of jurisdiction. In the context of the SAA that coordination should reflect not only harmonisation of entity legislationbut also the adoption of EU standards in this field. In this regard, the capacities of the Directorate for European Integration $\mathrm{B} \& \mathrm{H},{ }^{15}$ in charge of coordinating the various levels of government on the adoption of the acquis communautaire, have proved insufficient. Meanwhile, B\&H has established a coordination mechanism, ${ }^{16}$ which caused conflicting opinions concerning the uncertainties regarding the execution of specific responsibilities of individual government levels. Time will show to what extent this could be deemed an adequate coordination mechanism for the effective fulfillment of obligations from the EU integration process.

\footnotetext{
${ }^{13}$ Decision of the Constitutional Court No. U-5/98, http://www.ccB\&H.ba/bos/odluke/index.php?src=2, visited 26. 5. 2015.

${ }^{14}$ Official Gazette of B\&H, No. 59/07 and 59/09.

${ }^{15}$ The $\mathrm{B} \& \mathrm{H}$ Directorate for European Integration is responsible for tasks related to the harmonization of the activities of the authorities in $\mathrm{B} \& \mathrm{H}$, bearing in mind the obligations arising from the Euro-integration process. The Directorate also performs other tasks related to launching initiatives and advising on the issues of harmonization of the overall processes and activities of the authorities in B\&H to fulfill the obligations towards European integration process. Article 23(1) and (3) Act on the Council of Ministers, Official Gazette B\&H, No: 30/03, 42/03, 81/06, 76/07, 81/07, 24/08 and 94/07.

${ }^{16}$ Decision on the system of coordination for the EU integration process. Official Gazette B\&H, No. 8, 9.2.2016.
} 
To summarize the possibilities to implement EU private international law standards into the legislation of $\mathrm{B} \& \mathrm{H}$, there are the following three options:

- adoption of the Act on private international law on the state level, with the consent of both entities;

- adoption of the Framework Law on private international law, where the jurisdiction for harmonisation of the law in the area remains at the entitiy level, and

- adoption of new entity Acts on private international law with efficient mechanisms of coordination, that would be mutually harmonised and that would adopt EU standards in the area.

Bearing in mind that the area of private international law in the EU is realised mainly via Regulations, that in the Member States of the EU have direct and obligatory effect, it is necessary during the possible reform in the area to take into consideration standards of international private law of the EU. However, the question remains open whether in the pre-accession periods the candidate states must transpose Regulations into their national laws. Arguments against the transposition of Regulations into national laws arise from their character. Regulations are directly applicable, and therefore the legislation of the South-East-European (hereinafter: SEE) states will be in line with them as soon as they become Member States. In addition, according to established practice of the European Court of Justice (hereinafter: CJEU), the transposition of Regulations into national legislation is not allowed. ${ }^{17}$ In line with such considerations, Croatia as the most recent new Member State of the EU did not implement EU Regulations on private international law before becoming a Member State of the EU. Consequently, probably it would be possible for B\&H to become a Member State of the EU with the current legislation on private international law without using any of the three abovementioned options. On the other hand, it seems unreasonable that the obligation from the harmonization clause only applies to Directives, where the Member States often agreed only on a minimum common content, while Regulations which are binding in their entirety do not need to be transposed before the accession to the EU (Meškić, 2016: 242). Consequently, other

\footnotetext{
${ }^{17}$ Case 34/73, Fratelli Variola S.p.A. v Amministrazione italiana delle Finanze, ECLI:EU:C:1973:101.
} 


\section{LEXONOMICA \\ J. Alihodžić, Z. Meškić \& A. Duraković: Accepting EU Private International Law Standards into the Legal System of Bosnia and Herzegovina: What Can Be Done While

Western Balkans states have also chosen the approach to transpose EU Regulations in their national laws in the pre-accession stage. ${ }^{18}$

\section{Accession to existing and the conclusion of new international conventions in the field of private international law}

\subsection{Development of private international law in $B \& H$ by accession to international conventions}

Bearing in mind the complexity of problems referring to the constitutional capacity for adoption of new legislation changing the existing private international law, and the general absence of concensus to make a step forward in the field, ${ }^{19}$ other options for acceptance of principles of EU private international law in the jurisdiction of B\&H must be considered. The possibility that in the sense should be taken into consideration is becoming party to international conventions in some areas of private international law where this is consistent with the EU acquis. This can be done in compliance with the regulation of Private International Law in $\mathrm{B} \& \mathrm{H}$, which emphasizes that regulations of this Law are not applied to private legal relations with international elements, if they are regulated by an international treaty. ${ }^{20}$ Bearing in mind the obligation to harmonise jurisdiction in $\mathrm{B} \& \mathrm{H}$ with the $\mathrm{EU}$ acquis communautaire, the significance of conventional regulation of private international law is three-fold for B\&H.

First, it would be relevant for B\&H to access those conventions in the field of private international law to which the EU is a member. This primarily refers to the Hague Conventions, which will be discussed further in this paper. The second option is the conclusion of regional agreements, namely the accession to regional agreements, which are based on the principles of the EU private international law. The Lugano

\footnotetext{
${ }^{18}$ This is the approach most clearly visible in the Private International Law Act of Montenegro, Official Gazette of Montenegro, No 1/2014, of 9. 1. 2014 and 6/2014, of 17. 1. 2014.

${ }^{19} 2011$, at the initiative of the German organisation GIZ, a meeting of a working group for the reform of private international law in B\&H was held with representatives of the Ministry of Justice of B\&H and legal experts. Altough the group has met several times a consensus could not be reached especially on the question of competence for adoption of a new Act. Namely, the representatives of the experts from RS, as well as representatives of the official authorities from one entity, argued in favor of adoption of a new act at the entity level, while the rest of the working group from FB\&H opted for the adoption of the Act on private international law at the state level.

${ }^{20}$ Article 3 of the PIL Act of B\&H.
} 
Convention can be used as a role model. This possibility will also be discussed later in the paper. Thirdly, under certain conditions, there is a possibility of concluding bilateral agreements between B\&H and the EU Member States in certain areas of prívate international law. In this regard, the EU mechanisms that allow for this possibility should be considered, bearing in mind however the external jurisdiction of the EU for the regulation in the field of private international law.

\subsection{EU membership of the Hague Conference and the importance of its conventions for $B \& H$}

Additionally, general integration flows within the EU, the acquisition of external competence of the EU to enter into treaty relations with third countries, and the approach to international organisations, each were reflected in the institutional and legal framework of the Hague Conference. Furthermore, amendments were made to the Statute of the Hague Conference in order to enable organisations of regional economic integration, ${ }^{21}$ the EU included, to participate in its work. On 3 April 2007, what was then the EC, in accordance with the Article 3(3) of the Statute of the Hague Conference, submitted a declaration of competence, by which it became a member of the Hague Conference. The EU Member States, however, retain competence in all matters not covered by the declaration of the transfer of competence. The external competence of the EU, and therefore the membership of the EU in the work of the Hague Conference, has had a negative impact on the significance of the Hague Conventions when it comes to the mutual relationship between the EU Member States. On a more positive note, at the same time, its significance has grown with regards to relationships with third countries (Schulz, 2007: 940). ${ }^{22}$

The common work of the Hague Conference and the EU, characterized by their institutionalized cooperation, should be considered through the prism of the overwhlemingly positive outcomes of their joint interaction: The Hague Choice of Court Convention of 2005, The Hague Protocol on the Law Applicable to

\footnotetext{
${ }^{21}$ See https://www.hcch.net/de/news-archive/details/?varevent=125 (22. 2. 2018)

${ }^{22}$ Here primarily the relationships between the EU and USA, Russia and China are meant; See Schulz, A., "The Accession of the European Community to the Hague Conference on Private International Law" (2007) 56 International and Comparative Law Quarterly 940; The participation of several EU candidate states in the Hague Conference is also of importance, including $\mathrm{B} \& \mathrm{H}$ as a potential candidate state. Therefore, with the dissolution of the SFRY all of the newly independent states became members of the Hague Conference: Slovenia on 18. 6. 1992, Macedonia on 20. 9. 1993, Croatia on 12. 6. 1995, Serbia on 26.4.2001, B\&H on 7. 6. 2001 and Montenegro on 1.3. 2007.
} 


\section{LEXONOMICA \\ J. Alihodžić, Z. Meškić \& A. Duraković: Accepting EU Private International Law Standards into the Legal System of Bosnia and Herzegovina: What Can Be Done While

Maintenance Obligations of 2007 together with the Hague Convention on the International Recovery of Child Support and Other Forms of Family Maintenance of 2007 and the Hague Principles on Choice of Law in International Commercial Contracts of 2015.

B\&H so far has only ratified the Hague Child Support Convention of 2007. This is the most successful of the instruments commonly created by the EU and the Hague Conference, not just because it has a slightly larger number of ratifications, but also because the U.S. is one of the state parties. ${ }^{23}$ The reason for the success probably lies with the fact that it follows the concept of the New York Convention on the Recovery Abroad of Maintenance of $1956,{ }^{24}$ which places heavy emphasis on the coordination mechanism of international legal assistance through the Central Authorities in order to facilitate crossborder claims between the debtor and creditor in maintenance relations (Basedow, 2015: 343). The corresponding instrument on the applicable law to maintenance obligations, the Hague Protocol of 2007, was not ratified by B\&H and to date the only country from the SEE region to have ratified the Protocol is Serbia. ${ }^{25}$ Considering that during the period of time of ratification B\&H and Serbia agreed to jointly ratify the Hague instruments on maintenance relation, it might well have been a result of miscommunication that $\mathrm{B} \& \mathrm{H}$ ratified the convention and Serbia ratified the procotol.

There were some serious efforts in the region to ratify the Hague Choice of Court Convention of 2005, led by a regional conference in Zenica (B\&H) in 2015 (V. Loon, 2015: 11; Brand, 2015: 31; Alihodžić, 2015: 109-111). Unfortunately, only Montenegro from the SEE region eventually joined the Convention, ${ }^{26}$ although the ratification of this Convention was on the working agenda of the Ministry of Justice of B\&H for the year 2016, as an outcome of the regional conference. The Hague Choice of Court Convention of 2005 is a result of the efforts of U.S. lawyers to adopt a convention simple on recognition of foreign decisions and the already established British model of the convention double on jurisdiction and recogniton of foreign

\footnotetext{
${ }^{23}$ https://www.hcch.net/de/instruments/conventions/status-table/?cid=131 (12. 11. 2018)

${ }^{24}$ Official Gazette of Federal People's Republic of Yugoslavia, appendix - No. 2/60; B\&H became a party to the Convention by notification of succession,

https://reaties.un.org/pages/ViewDetailsIII.aspx?src=TREATY\&mtdsg_no=XX-

$1 \&$ chapter $=20 \&$ Temp $=$ mtdsg3\&clang=_en $\# 3$ (12. 11. 2018).

${ }^{25} \mathrm{https} / / /$ www.hcch.net/en/instruments/conventions/status-table/?cid=133 (12. 11. 2018).

${ }^{26} \mathrm{https}: / /$ www.hcch.net/en/instruments/conventions/status-table/?cid=98 (12. 11. 2018).
} 
decisions. The common ground was found in the unified rules on the choice of court (Basedow, 2017: 197). One of the advantages of the ratification by B\&H would be to establish the reciprocity between $\mathrm{B} \& \mathrm{H}$ and certain Member States of the EU in contractual relations, where some of them, e.g. Austria, require reciprocity based on an international agreement and so far do not recognise decisions from $\mathrm{B} \& \mathrm{H}$ in contractual matters. Considering the presence of the Austrian banks and insurance companies in $\mathrm{B} \& \mathrm{H}$, establishing reciprocity with Austria in contractual relations should be placed high on the B\&H agenda. The EU ratified the Hague Choice of Court Convention in 2015.

A further interesting project finished under the Hague Conference, but whose outcome was significantly influenced by the EU membership to the Hague Conference (Dieter, 2015: 625-627), is the Hague Principles on Choice of Law in International Commercial Contracts of 2015. ${ }^{27}$ The Hague Choice of Law Principles of 2015 are only a legally non-binding model law that serves the national legislators as a guideline for the reform of their conflict rules and were already used by Paraguay. ${ }^{28}$ The Hague Choice of Law Principles of 2015 therefore require legislation to be adopted by the legislator and this option is, as previously analyzed, not very likely to be used in $\mathrm{B} \& \mathrm{H}$. It is only recommendable that in future legislative reforms, once it becomes possible to conduct such reforms, the Hague Choice of Law Principles in 2015 should be taken into consideration as should the Regulation (EC) No 593/2008 of the European Parliament and of the Council of 17 June 2008 on the law applicable to contractual obligations (Rome I). ${ }^{29}$

It should also be mentioned that the EU adopted a decision in 2008 to authorize and encourage all EU Member States to join the 1996 Hague Convention on Jurisdiction, Applicable Law, Recognition, Enforcement and Cooperation in respect of Parental Responsibility and Measures for the Protection of Children. ${ }^{30}$ Contrary to the other Hague Conventions mentioned above, it was not possible for the EU to became a party, but rather only its individual Member States, and yet by 2016 all EU Member States joined the Convention. Also, Albania, Montenegro and Serbia from the SEE

\footnotetext{
${ }^{27} \mathrm{https}: / /$ www.hcch.net/de/instruments/conventions/full-text/?cid=135 (12. 11. 2018).

${ }^{28}$ Paraguayan Law 5393 of 2015 regarding the applicable law to international contracts, https://www.hcch.net/de/publications-and-studies/details4/?pid=6300\&dtid=41 (12. 1. 2018.).

${ }^{29}$ OJ EU L 177, 4. 7. 2008, p. 6.

${ }^{30}$ Council decision, OJ EU L 151, 11. 6. 2008, p. 36.
} 


\section{LEXONOMICA \\ J. Alihodžić, Z. Meškić \& A. Duraković: Accepting EU Private International Law Standards into the Legal System of Bosnia and Herzegovina: What Can Be Done While

joined the Hague Child Protection Convention of $1996,{ }^{31}$ but so far not B\&H. It is interesting that with regards to this Convention, it suffices if the contracting parties under Article 58(3) of the Hague Child Protection Convention do not object to the accession of new state parties. The EU Commission and the Member States in 2013 agreed that there is no reason to object to the accession by the Russian Federation (Mansel, Thorn, Wagner, 2014: 8-9).

According to the CJEU Opinion 1/13 of 14 October 2014, the EU claims to have exclusive competence for the acceptance of the accession of a third State to the Hague Conventions. Although the Opinion 1/13 is expressed only with regards to the Hague Convenion on the Civil Aspects of International Child Abduction of 25 October $1980,{ }^{32}$ and despite the justified criticism on this Opinion of the CJEU, ${ }^{33}$ it is to be expected that the EU would adopt the same opinion for all of the abovementioned Hague Conventions on the grounds that the EU has exersized its internal competence in that matter. The EU, instead of the individual EU Member States, therefore has exclusive competence for the acceptance of the accession of B\&H to any of the Hague Conventions considered above. This is problematic from the theoretical perspective, but in practise there is no reason why the EU would not accept the accession of $\mathrm{B} \& \mathrm{H}$ to any of these Conventions, considering that $\mathrm{B} \& \mathrm{H}$ is a potential candidate state waiting for its candidate status and that these Conventions will become binding in B\&H anyway once it becomes a Member State.

Consequently, ratification of Hague Conventions already ratified by the EU or all of its Member States is currently the most appropriate way for B\&H to harmonize with the EU legislation in the field of private international law.

\footnotetext{
${ }^{31} \mathrm{https}: / /$ www.hcch.net/en/instruments/conventions/status-table/?cid=70.

${ }^{32}$ The Republic of Armenia, the Republic of Albania, the Republic of Seychelles, the Kingdom of Morocco, the Republic of Singapore, the Gabonese Republic, the Principality of Andorra and the Russian Federation successively deposited instruments of accession to the 1980 Hague Convention. Taking the view that the question of the international abduction of children fell within the exclusive external competence of the EU, the Commission adopted, on 21 December 2011, eight proposals for decisions of the Council of the European Union concerning the declarations of acceptance by the Member States, of the accession of those eight third States to the 1980 Hague Convention. However, within the Council most of the representatives of the Member States considered that the Council does not have to adopt those proposals, because the EU in their view, does not have exclusive competence in the area concerned. Therefore, the Commission considered it appropriate to submit the present request for an opinion to the Court pursuant to Article 218(11) Treaty on the functioning of the European Union (OJ EU C 326, 26. 10. 2012, p. 47).

${ }^{33}$ Beaumont, P., 'A Critical Analysis of the Judicial Activism of the Court of Justice of the European Union in Opinion 1/13', working paper available at:

https://www.abdn.ac.uk/law/documents/Opinion_on_Child_Abduction_-_Judicial_Activism_by_the_CJEU_By_Beaumont.pdf(12.11.2018).
} 


\subsection{Regional conventions in the field of private international law - Sarajevo Convention, a missed opportunity}

One of the possibilities for adoption of the EU standards in the field of private international law in $\mathrm{B} \& \mathrm{H}$ is to conclude regional agreements in the field of private international law that are consistent with relevant EU acts. ${ }^{34}$ When it comes to the procedural rules of private international law (rules on jurisdiction, recognition and enforcement of judgments in civil and commercial matters), the accession of the Western Balkans countries including B\&H to the Lugano Convention on jurisdiction and recognition and enforcement of judgments in civil and commercial matters (Lugano Convention) ${ }^{35}$ was considered. However, due to the provisions of the Article 70(1) and the Article 72(1)(c) of the Lugano Convention, third countries can accede to this convention only after the fulfillment of certain conditions, and the ultimate aim is to ensure the trust of the Contracting States of the Lugano Convention in the judicial system of the candidate state. The leading legal authority in the field of private international law in SEE thought that this should be a "regional step" towards the European legal space. However, it is evident that all the states in the region do not have the opportunity to accede to the Lugano Convention at the same time (Stanivuković, 2010: 100).

Due to the significant number of international agreements that already have been signed in the field of the procedural private international law between the Western Balkans countries, a certain degree of trust has already been established in the work of legal institutions of these countries. This trust served as a basis for an original idea of the need for creation of a regional convention based on the content of the Regulation No 44/2001 of 22 December 2000 on jurisdiction and the recognition and enforcement of judgments in civil and commercial matters ${ }^{36}$ (Brussels I Regulation). Initiated by the Republic of Slovenia in 2011, ministers and legal representatives from the CEFTA Member States met to follow up on this idea in Sarajevo and that is why the later draft Convention was informally called the Sarajevo Convention (Meškić, Radončić, 2013: 55-80) However, there was a dilemma on the issue whether to adopt only the basic principles from the Brussels I Regulation and make

\footnotetext{
${ }^{34}$ A conference was held on the topic: "Enlargement of the European Judicial Area to CEFTA Countries" in Novi Sad in 2009.

${ }^{35}$ OJ EU L 339, 21. 12. 2007, p. 3.

${ }^{36}$ OJ EU L 12, 16. 1. 2001, p. 1.
} 


\section{LEXONOMICA \\ J. Alihodžić, Z. Meškić \& A. Duraković: Accepting EU Private International Law Standards into the Legal System of Bosnia and Herzegovina: What Can Be Done While

a shorter version for the states of the Western Balkans, or to transpose its content fully to the new regional convention. Furthermore, the political impact of adopting a shorter version would be much lower, aa the states of the region would would do little in terms of providing harmonisation with EU law or for practicing the application of EU law before accession. When the decision ultimately was made to copy and paste Brussels I into the Sarajevo Convention, suggestions were made to improve the text based on the Brussels I Recast. Namely, one should bear in mind that the negotiations about the Convention were ongoing at the time when it was certain that there would be changes in the EU to the text of the Brussels I Regulation. The proposal was to overcome this problem with the Protocol no. 3 to the Convention, according to which the contractual parties are obliged to align the provisions of the Convention with the changes to the Brussels I Regulation as much as possible. For the question of interpretation of the Convention, the representatives of the CEFTA states agreed on the model of Protocol no. 2 to the Lugano Convention, meaning that the courts of the Contracting States with respect to a specific matter, should take into account the jurisprudence of the CJEU. Expectations that the Sarajevo Convention would be open to ratification by the end of 2013 proved to be illusory. Unfortunately, the Sarajevo Convention was never officially opened for ratification, and considering the current political situation in the region, ${ }^{37}$ there is almost no hope that this convention will ever enter into force.

\subsection{Conclusion of bilateral agreements between Member States and third countries}

$\mathrm{B} \& \mathrm{H}$, in its young history as an independent state, was quite active in concluding bilateral agreements in the field of private international law. By virtue of succession from the Yugoslavia, B\&H has entered into over twenty bilateral treaties on legal assistance in civil matters, recognition and enforcement of judgments and civil procedure. After the independence, B\&H ratified bilateral agreements in civil matters foremost with the states of the region, but also for example with China and Turkey. ${ }^{38}$

\footnotetext{
${ }^{37}$ Although Serbia was one of the initiators of the meeting in Sarajevo, for now it does not show any interest to ratify the Convention.

${ }^{38}$ The full list of international and bilateral treaties ratified by B\&H can be found at the website of the Ministry of Justice of B\&H:

http://www.mpr.gov.ba/organizacija_nadleznosti/medj_pravna_pomoc/bilateralni_ugovori/Konvencije.aspx?1 angTag=en-US $(12.11 .2018)$
} 
This means that the conclusion of bilateral agreements with EU Member States from the perspective of B\&H would be a very welcomed option.

From the EU perspective, interpretation given in ERTA $^{39}$ and other connected cases (Brand, 2005: 287), ${ }^{40}$ as well as opinions ${ }^{41}$ of the CJEU, practically had, and indeed still have, far-reaching consequences as regards the conclusion of international treaties between the EU Member States and third countries. In accordance with the aforementioned interpretation of the CJEU, if the EU unified certain fields of private international law completely, to the extent that its provisions shall also include citizens of third countries, Member States shall lose their competence in these fields. Namely, the rules established in that manner might be endangered, if in addition to the EU, the Member States also retain external competence for the regulation of the same issues with third countries. Consequently, the Member States lose the opportunity of concluding international agreements with third countries in the part of private international law that is completely regulated by binding instruments of EU law. This legal status in practice can result in certain difficulties. For example, if the Member State wants to conclude a new, or modify an existing, bilateral agreement with a state that is not an EU Member, it must seek a decision of the Council, proposed by the Commission, that gives it the authority to conclude a bilateral agreement (Kruger, 2006: 198). That is, namely, established practice of action of the Member States in the domain that is exclusively under the external competence of the EU. ${ }^{42}$ However, when it comes to bilateral agreements, it is highly probable that this procedure proved to be inefficient in practice, since all the Member States, represented in the Council, do not have the same interest for conclusion of international agreements with certain third countries (Kruger, 2006: 198). In the wake

\footnotetext{
${ }^{39}$ Case 22/70, Commission of the European Communities v Council of the European Communities, ECLI:EU:C:1971:32.

${ }^{40}$ Open Skies Judgments in 2002: case C-467/98, Commission of the European Communities v Kingdom of Denmark, ECLI:EU:C:2002:625; case C-468/98, Commission of the European Communities v Kingdom of Sweden, ECLI:EU:C:2002:626; case C-469/98, Commission of the European Communities v République de Finlande, ECLI:EU:C:2002:627; case C-471/98, Commission of the European Communities v Kingdom of Belgium, ECLI:EU:C:2002:628; case 472/98, Commission of the European Communities v Grand Duchy of Luxemburg, ECLI:EU:C:2002:629; case C-475/98, Commission of the European Communities v Republic of Austria, ECLI:EU:C:2002:630, and the case C-476/98, Commission of the European Communities v Federal Republic of Germany, ECLI:EU:C:2002:631. See Brand, 2005: 287.

${ }^{41}$ Opinion 1/94, Competence of the Community to conclude international agreements concerning services and the protection of intellectual property - Article 228 (6) of the EC Treaty, ECLI:EU:C:1994:384, Opinion 1/03, Competence of the Community to conclude the new Lugano Convention on jurisdiction and the recognition and enforcement of judgments in civil and commercial matters, ECLI:EU:C:2006:81, and lastly Opinion 1/13 on international child abduction, OJ EU C 462, 22. 12. 2014, p. 4.

${ }^{42}$ Opinion 1/94, ECLI:EU:C:1994:384, para. 106-109.
} 
of this, on 7 July 2009 the Council adopted the Regulation 664/2009 establishing a procedure for the negotiation and conclusion of agreements between Member States and third countries concerning jurisdiction, recognition and enforcement of judgments and decisions in matrimonial matters, matters of parental responsibility and matters relating to maintenance obligations, and the law applicable to matters relating to maintenance obligations (Regulation 664/2009). ${ }^{43}$ The Regulation $664 / 2009$ establishes the procedure for negotiations and conclusion of agreements between the Member States and third countires considering jurisdiction, recognition and enforcement of court and other judgments in matrimonial matters, matters of parental responsibility, and matters that refer to the maintenance obligations, and the right apllicable to maintenance obligations. The parallel Council Regulation 662/2009 of the European Parliament and of the Council of 13 July 2009 establishing a procedure for the negotiation and conclusion of agreements between Member States and third countries on particular matters concerning the law applicable to contractual and non-contractual obligations (Regulation 662/2009) ${ }^{44}$ establishing a procedure for the negotiation and conclusion of agreements between Member States and third countries on particular matters concerning the law applicable to contractual and noncontractual obligations was adopted on 13 July 2009.

The need to enter into bilateral relations between the Member State and a third state, is often conditioned by the fact that a significant part of the population of a certain third state lives in the EU Member State, or in the case that the third state borders with the Member State. Since the EU interests in certain issues of the EU private international law, which applies particularly to the area of personal rights and family relations, do not have to be (and often are not) complementary to the interests of individual Member States, the adoption of the regulation in terms of providing opportunities to the Member States to enter into treaty relations with third countries is essential.

Thus, the Regulations 662/2009 and 664/2009 established procedures in accordance with which it can give the authorisation to the Member State to amend an existing or enter into negotiations and conclude a new agreement with a third country, in the area of jurisdiction, recognition and enforcement of judicial and other decisions in

\footnotetext{
${ }^{43}$ OJ EU L 2000, 31. 7. 2009, p. 46.

${ }^{44}$ OJ EU L 200, 31. 7. 2009, p. 25.
} 
contractual and non-contractual obligations and family cases respectively. However, the provisions of these Regulations shall not be applied if the EU has already concluded, or within 24 months intends to conclude, agreements with the third country on the same legal issue. ${ }^{45}$ Although the option is left to the Member States under certain conditions ${ }^{46}$ to enter into bilateral treaties with third states, the validity of such agreements is restricted in advance by the clauses that would stipulate that a later multilateral treaty between that third state and the EU on the same issue, would in part or as a whole set aside the provisions of the bilateral agreement. ${ }^{47}$ Consequently, if the EU so far has not shown interest in that direction, there is a legal possibility for the Member States to conclude bilateral agreements with third states in the field of EU private international law. ${ }^{48}$

This would, at least in theory, be an option for B\&H for at least two reasons. First, the dissolution of former Yugoslavia left a multiplier effect both in B\&H, as well as to other countries of the region in terms of creating a new international-legal environment. Namely, Croatia has already become a member of the EU, while it is almost certain that B\&H will become member of the EU later than other countries in the region, and in this context raises problems in the bilateral relations in the field of private international law (primarily recognition and enforcement of judicial and other decisions) between $\mathrm{B} \& \mathrm{H}$ and these countries. ${ }^{49}$ Second, the war and post-war events that befell this region were the catalyst for the migration of a large percentage of the population of B\&H to the EU Member States. In practical terms, however, the Member States would need to have a high level of motivation in order to undergo the complicated procedures under the Regulations 662/2009 or 664/2009 to conclude a bilateral agreement with B\&H. So far, neither B\&H nor any of the Member States initiated this procedure.

\footnotetext{
${ }^{45}$ Article 4(2) of the Regulations 662/2009 and 664/2009.

${ }^{46}$ The conditions are laid down in Article 4(2) of the Regulations 662/2009 and 664/2009.

${ }^{47}$ Article 5(2) of the Regulations 662/2009 and 664/2009.

${ }^{48}$ Regulations 662/2009 and 664/2009, recital 8.

${ }^{49} \mathrm{~B} \& \mathrm{H}$ already concluded some agreements which, considering the subject matter of their regulation and the future EU membership of some of these states, will in part or as a whole fall under Regulation 664/2009. These agreements are legal aid agreements in civil and criminal matters available at:

www.mpr.gov.ba/organizacija_nadleznosti/medj_pravna_pomoc/bilateralni_ugovori/Konvencije.aspx?langTa $\mathrm{g}=\mathrm{en}-\mathrm{US}$.
} 


\section{LEXONOMICA \\ J. Alihodžić, Z. Meškić \& A. Duraković: Accepting EU Private International Law Standards into the Legal System of Bosnia and Herzegovina: What Can Be Done While

\section{Conclusion}

The reform of private international law in $\mathrm{B} \& \mathrm{H}$, considering the current political situation, has little chance of success. It is, as opposed to the reforms implemented in this area in other countries of the region, burdened by the inability to achieve a political consensus on this question of competence, which requires compromise of competent institutions of different levels of government in B\&H. According to constitutional capacities, and counting on eventually achieved consensus among the entities, the reform of private international law in the sense of a new law in this area could result in:

- adoption of the Private International Law Act at the state level, with the consent of entities;

- adoption of the Framework Act on Private International Law, where the competence for a more detailed regulation of the matters governed by the Framework Act remains at the entity level, and

- adoption of entity Private International Law Acts via efficient mechanisms of coordination, that would be mutually harmonised and that would adopt the EU standards in this field.

However, the use of the above constitutional possibilities requires a high level of consensus in view of the very complicated procedures and decision-making mechanisms and ethnic blocks. The frequent use of these mechanisms has led to a halt of $\mathrm{B} \& \mathrm{H}$ in terms of fulfillment of obligations arising from the SAA, which entered into force in 2015. It has led to the fact that the reform in this legal field through the adoption of the new act has made no significant progress, despite the clear position of the professional and scientific community speaking in favour of it.

The ongoing failure of reforms can be considered a sufficient reason to consider alternative ways of introducing standards of EU private international law in the legislation in $\mathrm{B} \& \mathrm{H}$. The primary alternative way proposed in this paper is the accession of $\mathrm{B} \& \mathrm{H}$ to those international conventions which the EU is a party to. This primarily refers to the conventions adopted in the framework of the Hague Conference on Private International Law, which in accordance with the external competence of the EU on behalf of the Member States were signed and adopted by the EU. B\&H so far ratified only the Hague Maintenance Convention of 2007. B\&H should strongly consider ratifying The Hague Choice of Court Convention of 2005, 
The Hague Maintenance Protocol of 2007 and The Hague Child Protection Convention of 1996 as soon as possible.

The other two alternative options are much less likely to be used because of the complexity of the procedures, although they would be very effective. The first such option represents the conclusion of regional agreements, for which the Lugano Convention would serve as a model, and which are substantially in line with the relevant legal instruments of the EU. Unfortunately, this option was already followed with the regional Sarajevo Convention, but can today be declared to have failed.

The second, but also not very probable option, is provided by Regulations 662/2009 and 664/2009. These Regulations provide Member States with the option, regardless of established external competence of the EU in this field, to enter into treaty relations with third countries, including B\&H. Such agreements would be concerned with questions of jurisdiction, recognition and enforcement of foreign court decisions in the matter of double items, parental responsibility and maintenance, as well as the law applicable to maintenance obligations, and contractual and non-contractual obligations. These mechanisms have not been used in the case of B\&H yet. The Member State wishing to enter into such bilateral agreements with B\&H would need to invest a lot of effort to follow the procedures provided by the Regulations 662/2009 and 664/2009, something they well might not be willing to do, and even then the outcome would still be unpredictable, because of the approval required by the EU.

It remains to be seen which of the above'elaborated possibilities competent institutions in $\mathrm{B} \& \mathrm{H}$ will opt for. What is certain for the time being is that one or more of the options need to be chosen as soon as possible in order to fulfill obligations under the SAA and to make the aspirations towards EU Membership more credible.

\section{References}

Alihodžić, J. (2015) The Hague Convention 2005 and Bosnia and Herzegovina, Anali Pravnog fakulteta Univerziteta u Zenici, 9, pp. 109-111.

Basedow, J. (2015) Gegenseitigkeit im Kollisionrecht in: Hilbig-Lugani, K., (ed.) Zwischenbilanz - Festschrift für Dagmar Coester-Waltjen, Gieseking, Bielefeld, pp. 335-349.

Basedow, J. (2017) EU-Kollisionrecht und Haager Konferenz - Ein schweriges Verhältnis, IPRax, 37(2), pp. 194-200. 


\section{LEXONOMICA}

J. Alihodžić, Z. Meškić \& A. Duraković: Accepting EU Private International Law Standards into the Legal System of Bosnia and Herzegovina: What Can Be Done While

Brand, R. (2005) The European Union's New Role in International Private Litigation, Loyola University Chicago International Law Review, 2(2), pp. 277-293.

Brand, R. (2015) The 2005 Hague Choice of Court Convention in the United States, Anali Pravnog fakulteta Univerziteta u Zenici, 9(18), pp. 31-45.

Dieter, M. (2015) Die Haager Principles on Choice of Law in International Commercial Contracts Eine weitere Verankerung der Parteiautonomie, RabelsZ, 79(3), pp. 624653.

Kruger, T. (2006), Opinion 1/03, 'Competence of the Community to Conclude the New Lugano Convention on the Jurisdiction and the Recognition and Enforcement of Judgments in Civil and Commercial Matters, Columbia Journal of European Law, 13(1), pp. 189-201.

Mansel, H.P., Thorn, R., Wagner, R. (2014), Europäisches Kollisionrecht 2013: Atempause im status que, IPRax, Heft 1, pp. 1-27.

Meškić, Z. (2016) Regional Convention on Jurisdiction and the Mutual Recognition and Enforcement of Judgments in Civil And Commercial Matters (Sarajevo Convention) - A Perspective of Bosnia And Herzegovina, in Liber Amicorum Gaša Knežević, Belgrade, pp. 242-267.

Meškić, Z., Radončić, Dž. (2013), Brussels I recast and the south-east Europe, Revija za evropsko pravo, 15(1), pp. 55-80.

Muminović, E. (1998) O uzajamnom odnosu načela najuže veze, autonomije volje i favorabilnosti mjerodavnog prava u vezi s potrebom zakonodavnog djelovanja države Bosne i Hercegovine u materiji međunarodnog privatnog prava, Godišnjak Pravnog fakulteta u Sarajevu, 41, pp. 234-245.

Schulz, A. (2007) The Accession of the European Community to the Hague Conference on Private International Law, International and Comparative Law Quarterly, 56(4), pp. 939-949.

Stanivuković, M. (2010), Umjesto zaključka-o potrebi pristupanja Luganskoj konvenciji, Collected Papers from the VIIth Private International Law Conference-Enlargement of the European Judicial Area to CEFTA Countries, Novi Sad, pp.100-127.

V. Loon, H. (2015) The 2005 Hague Convention on the Choice of Court Agreements - An Introduction, Anali Pravnog fakulteta Univerziteta u Zenici, 9, pp. 11-31. 
174 LeXonomicA 